\title{
Volcanic Ash Application in Agricultural Practice
}

\author{
Lalita V. Zakharikhina ${ }^{1, *}$, Yury S. Litvinenko², Vera V. Gainatulina ${ }^{3}$ \\ ${ }^{1}$ Federal Research Centre the Subtropical Scientific Centre of the Russian Academy of Sciences, \\ Krasnodar Territory, Sochi, Russian Federation \\ ${ }^{2}$ EcoGeoLit (LLC), Moscow, Russian Federation \\ ${ }^{3}$ Kamchatka Research Institute of Agriculture, Kamchatka Territory, Russian Federation
}

Received October 13, 2021; Revised November 7, 2021; Accepted November 22, 2021

\begin{abstract}
Cite This Paper in the following Citation Styles
(a): [1] Lalita V. Zakharikhina, Yury S. Litvinenko, Vera V. Gainatulina, "Volcanic Ash Application in Agricultural Practice," Universal Journal of Agricultural Research, Vol. 10, No. 1, pp. 77 - 87, 2022. DOI: 10.13189/ujar.2022.100107.
\end{abstract}

(b): Lalita V. Zakharikhina, Yury S. Litvinenko, Vera V. Gainatulina (2022). Volcanic Ash Application in Agricultural Practice. Universal Journal of Agricultural Research, 10(1), 77 - 87. DOI: 10.13189/ujar.2022.100107.

Copyright $\mathrm{C} 2022$ by authors, all rights reserved. Authors agree that this article remains permanently open access under the terms of the Creative Commons Attribution License 4.0 International License

\begin{abstract}
For the first time in international practice, agricultural experiments were carried out to introduce volcanic ash from the Kamchatka Peninsula in combination with conventional mineral fertilizers into ocherous volcanic soils (Andosols Acroxic). According to various variables of field experiment, yield increases were obtained relative to the background: for potatoes (Solanum tuberosum) by $31-63 \%$ in 2014 , by $7-19 \%$ in 2017 and by $14-31 \%$ in 2018; on timothy (Phleum pretense) by $21-50 \%$ in 2015. Production experience in the cultivation of annual forage grasses in 2016 showed an increase in yield by $32 \%$. In addition, the crude protein in forage grasses and the content of starch potato tubers also increase, and potatoes have better resistance to potato diseases.
\end{abstract}

Keywords Kamchatka, Volcanic Ash, Improving the Biological Productivity of the Soil, Increased Productivity of Agrocenoses

\section{Introduction}

The use of unconventional fertilizers of natural origin in agricultural practice is an actively developing scientific direction aimed primarily at obtaining environmentally friendly products. Known examples of research on the effectiveness of various organic and mineral additives are: biochar (specially prepared charcoal) [1,2], betaine (a natural component of plant origin obtained from seafood, spinach, beetroot and cereals) [3], humic substances and zeolite [4], various biofertilizers [5,6], and biohumus [7,8]. Stone-mulch farming (volcanic ash and slag, pebbles, gravel or stones) is also used to improve crop growth [9]. In addition, volcanic ash can be considered an unconventional mineral fertilizer that improves the chemical properties of the soil. Questions about the potential fertility of volcanic ash (which supplies the soil with chemical elements and increases its bioproductivity after eruptions) have been extensively covered in the scientific and popular literature [10,11]. Volcanic ash is believed to absorb large amounts of carbon from the atmosphere and create fertile, humus-rich soils [12].

The potential beneficial effect of volcanic ash on the dual productivity of ecosystems is confirmed by data on the properties of both volcanic soils themselves and on other environmental components that form near active volcanoes. The products of volcanic eruptions form vast regions with specific soils developed on them - Andosoils [13] characterized by unique chemical and mineralogical features $[14,15]$. All volcanic soils are rich in phosphorus and have solid water-holding capacity; in warm climatic conditions, fertile soil horizons rich in humus are formed on volcanic ashes [13]. Vegetation with rich geochemical composition grows on Andosoils due to volcanic activity [16]. Emissions of gases from volcanic activity affect the properties of the atmosphere $[17,18]$. The easily moving shapes of the chemical elements of the ash determine the composition of natural solutions [19,20] and watercourses in the vicinity of volcanoes, especially during eruptions [21].

The main goal is to establish the effectiveness of the 
application of volcanic ash research in agricultural practice.

\section{Materials and Methods}

Field experiments were carried out in the Central Region of the Southern Soil Province of Kamchatka [22] on the experimental fields of Kamchatka Research Institute of Agriculture (KRIA). The lands of KRIA (south of Kamchatka, valley of the Avacha river) are located in the conditions typical of the southern agricultural zone of the peninsula. The production experiment is carried out in the same area on the fields of the 'Sosnovskoe' agricultural enterprise. The area is characterized by ocherous volcanic soils which (according to the Russian Soil Classification [23]) belong to the synlithogenic soils (volcanic soils section). According to the World Reference Base (WRB 2014 [24]), the soil is Andosols Acroxic.

The territories of the KRIA experimental fields are occupied by heterogeneous agro- volcanic transformed soils; it is characterized by high organic matter contents. Ignition losses in surface coarse humus horizons are $53-80 \%$. The humus content in organomineral horizons is high $-\mathrm{u}$ to $7-10 \%$. The reaction of the environment in the soils is acidic and slightly acidic. The degree of saturation with bases is low, $30-40 \%$ on average. The most saturated are the surface coarse-humus horizons $(40-60 \%)$. Soils, with the exception of the ocherous (middle) loamy horizon BAN, are characterized by a sandy loam granulometric composition. The content of fractions $<0.01$ $\mathrm{mm}$ is $5.6-7.7 \%$ in the organogenic horizons and $10-14.5 \%$ in the ash horizons. The density is low $(<0.9$ $\mathrm{g} / \mathrm{cm} 3$ ), and water retention capacity is good [25].

Agricultural experiments were conducted to introduce volcanic ash into the soils to improve its biological productivity in 2014-2018. According to the Kamchatka Department of Hydrometeorology and Environmental Monitoring, the growing season in 2014 was much warmer than usual (the sum of $\mathrm{t}>10^{\circ}$ was $23 \%$ higher than the long-term average). At the same time, the total amount of precipitation for the summer-autumn period of 2014 was $24 \%$ less than the long-term average. The year 2015 was the least favorable in terms of climatic conditions, characterized by the heaviest rainfall $(36 \%$ higher than the average annual) and the lowest temperatures. 2016 and 2017 in terms of temperature regime were close to the warm 2014 (the sum of $t>10^{\circ}$ was 18 and $22 \%$ higher than the average annual value, respectively). However, the amount of precipitation in these years is much higher than in 2014 and exceeded the average annual value. An increased in moisture was observed at the beginning of the growing season and in late summer and early autumn when agricultural crops were ripening. Compared to with 2016 and 2017, 2018 was somewhat colder but similar in terms of precipitation.

Freshly fallen volcanic sandy loam ashes of the medium-basic composition of the eruptions of the Shiveluch and the Bezymianny volcanoes were introduced into the soils.

Counting and observations were made according to generally accepted methods [26]. To assess the differences in the observed indicators for the experiment variants, the least significant difference was established at the $5 \%$ level of $\mathrm{LSD}_{05}$. The error of the difference $\mathrm{Sd}$ was determined taking into account the sampling error $\mathrm{Sx}_{1}$ calculated from the data of all repetitions of the experiment with ash addition, and the $\mathrm{Sx}_{2}$ value established from the results of repetitions on the background experiment without ash addition.

Field experiments were carried out on plots that had clean fallow for three years before the experiment, and were sown with oats in the previous year of the experiment. The average yield of oats from a test plot was 26.6/ha, the variation from the average for the test plots was $-0.7 \mathrm{t} / \mathrm{ha}$ to $+0.9 \mathrm{t} / \mathrm{ha}$. The LSD calculation $\left(\mathrm{LSD}_{05}-\right.$ $1.35 \mathrm{t} / \mathrm{ha}$ ) showed no statistically significant differences in the yield of oats across the plots of the site, which indicated the evenness of the experimental plots.

All experiment variables were carried out in four repetitions. The size of the experimental plots was $10 \mathrm{~m}^{2}$, the shape of the plots was rectangular. The placement of variants on the plots was carried out according to the systematic method (checkerboard). The width of the end guards was $2 \mathrm{~m}$, and that of the inter-level strips was $1 \mathrm{~m}$.

Ash was applied under potatoes in the amount of 2.5$7.5 \mathrm{t} / \mathrm{ha}$ in combination with mineral fertilizers. As a traditional mineral supplement, fertilizers containing the main nutrients were used: nitrogen, phosphorus, potassium, at doses of $120 \mathrm{~kg} / \mathrm{ha}\left(\mathrm{N}_{120} \mathrm{P}_{120} \mathrm{~K}_{120}\right.$ is the habitual dose used in the region), 90 and $60 \mathrm{~kg} / \mathrm{ha}$ of active ingredient. In 2017-2018, the effect of volcanic ash on potato yield was investigated, both against the background of mineral fertilizers and without their use.

With timothy, the influence of volcanic ash on the yield of grasses was studied against the background of mineral fertilizers $\left(\mathrm{N}_{90} \mathrm{P}_{90} \mathrm{~K}_{90}\right)$ and without their use. Ash doses in both cases were $2.5-5 \mathrm{t} / \mathrm{ha}$.

The production experiment was also implemented in 2016 on agrocherous volcanic soils of the 'Sosnovskoe' agricultural enterprise (the village of Sosnovka) and the area of 10 ha on annual forage grasses represented by a mixture of oats (spring Krechet variety, $160 \mathrm{~kg} / \mathrm{ha}$, 82.05\%), vetches (Lgovskaya-22), peas (Aksai mustached-55), barley (Acha, $10 \mathrm{~kg} / \mathrm{ha}, 5.13 \%$ ) and rapeseed (spring Lagonda, $5 \mathrm{~kg} / \mathrm{ha}, 2.56 \%$ ). Ashes were introduced into the soil by an MVU-5 mineral fertilizer spreader autonomously before mineral fertilizers, later introduced at the dose of $\mathrm{N}_{90} \mathrm{P}_{90} \mathrm{~K}_{90}$. The fertilizer and the ashes were introduced into the soil before sowing the grasses. 
To analyze the chemical composition of volcanic ash and agrocherous soils, the mobile forms of 65 elements were determined. The ammonium acetate extract $(\mathrm{pH}=$ 4.8) was analyzed by ICP-MS and ICP-AES analyzes without sample decomposition according to the Scientific Council for Analytical Research Methods certified method No. 500-MS "Determination of the elemental composition of nitric acid and ammonium acetate extracts from soils by inductively coupled plasma mass spectrometry". The solid phase:solution ratio was 1:10. Notably, based on the aforementioned technique, the technology of combined use of ICP-MS and ICP-AES methods was used which expands the spectrum of the determined chemical elements and allows additionally establishing ICP-AES by the method of $\mathrm{Na}, \mathrm{Mg}, \mathrm{Al}, \mathrm{K}, \mathrm{Ca}, \mathrm{Ti}, \mathrm{Fe}, \mathrm{Si}, \mathrm{P}$ and $\mathrm{S}$ content [27].

The content of 69 chemical elements in plants (potato tubers) was also determined using quantitative methods of analysis - ICP-MS and ICP-AES, according to the Scientific Council for Analytical Research Methods certified method No. 512-MS "Determination of the elemental composition of a plant sample by atomic emission analysis with inductively coupled plasma and mass spectral analysis with inductively coupled plasma".

The following indicators were assessed in the soils: $\mathrm{pH}$ of water and salt extracts (GOST 26483-85), hydrolytic acidity according to the Kappen method in the modification of Central Research Institute of Agrochemical Services for Agriculture (GOST 26212-91), the content of exchangeable forms of calcium and magnesium (complexometric method, GOST 26487-85), mobile phosphorus and potassium (by the Kirsanov reaction, GOST R 54650-2011). The content of nitrates and starch was determined in potato tubers (GOST 7194-81). The crop accounting was carried out using the continuous method. In the spring of 2015 and 2018, the parameters of keeping quality for experimental potatoes (kept after harvesting in the KRIA storages, autumn of the 2014 and 2017) were also established. Potato tubers affected with various diseases were counted piece-by-piece, and the percentage of healthy tubers from the total mass was established for each variant of the experiment.

Ash from the Shiveluch volcano, used in the experiment, was represented mainly by sandy loam, dusty material of the latest modern volcanic eruptions, selected from fresh sediments carried by the waters to the foot of the volcanic edifice. Sandy loam ashes of the Bezymianny volcano (1956 eruption) were taken from aerial deposits at some distance from the volcano.

\section{Results}

\section{Field experiments}

According to the various variables of the experiment in 2014 (only ash of the Shiveluch volcano), the potato yield increased by $31-63 \%$ relative to the background, $47 \%$ on average. In 2017, significant increases in yield when applying ash were lower - 6.6-18.5\% (Table 1). At the same time, a higher yield of experiment variants was observed with the introduction of ash from Bezymianny volcano.

Table 1. Effectiveness of the use of volcanic ash in the cultivation of potatoes

\begin{tabular}{|c|c|c|c|c|c|c|c|c|c|}
\hline \multirow{2}{*}{$\begin{array}{l}\text { Experiment } \\
\text { variant }\end{array}$} & \multicolumn{2}{|r|}{ Yield } & \multicolumn{2}{|c|}{ Starch } & \multicolumn{2}{|c|}{$\begin{array}{c}\begin{array}{c}\text { Rhizoctonia lesions on } \\
\text { tubers }\end{array} \\
\end{array}$} & \multicolumn{2}{|c|}{ Keeping quality } & \multirow{2}{*}{$\begin{array}{c}\begin{array}{c}\text { Economic } \\
\text { efficiency }\end{array} \\
\text { USD/ha }\end{array}$} \\
\hline & t/ha & $\begin{array}{c} \pm \text { to the } \\
\text { background, } \\
\%\end{array}$ & $\%$ & $\begin{array}{c} \pm \text { to the } \\
\text { background, } \\
\%\end{array}$ & $\%$ & $\begin{array}{c} \pm \text { to the } \\
\text { background } \\
\%\end{array}$ & $\begin{array}{c}\text { healthy } \\
\text { tubers, } \\
\%\end{array}$ &, $\pm \%$ & \\
\hline \multicolumn{10}{|c|}{2014} \\
\hline No fertilizers & 6.2 & $-*$ & 11.00 & - & 14.5 & - & - & - & - \\
\hline $\begin{array}{c}\text { Background }_{1-} \\
(\mathrm{NPK})_{120}\end{array}$ & 11.8 & - & 10.20 & - & 9.25 & & 66.1 & - & - \\
\hline $\begin{array}{l}\text { Background } \\
+\operatorname{ash}_{\mathrm{s}} 2.5 \mathrm{t} / \mathrm{ha} \\
\end{array}$ & 15.6 & +32.0 & 10.50 & +2.94 & 12.0 & +2.8 & 77.7 & +11.6 & 758 \\
\hline $\begin{array}{r}\text { Background }_{1} \\
+\operatorname{ash}_{\mathrm{s}} 5.0 \mathrm{t} / \mathrm{ha} \\
\end{array}$ & 15.5 & +31.0 & 11.00 & +7.84 & 8.0 & -1.3 & 85.0 & +18.9 & - \\
\hline 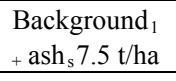 & 16.3 & +38.0 & 10.20 & +0.00 & 10.75 & +1.5 & 70.9 & +4.8 & - \\
\hline $\mathrm{HCP}_{0.5}$ & 1.2 & & & $0.52 \%$ & & & & $6.6 \%$ & - \\
\hline $\begin{array}{l}\text { Background }_{2-} \\
(\mathrm{NPK})_{60}\end{array}$ & 10.5 & - & 11.20 & - & 14.5 & & 63.0 & & - \\
\hline $\begin{array}{l}\text { Background }_{2} \\
+\operatorname{ash}_{\mathrm{s}} 2.5 \mathrm{t} / \mathrm{ha} \\
\end{array}$ & 16.5 & +57.0 & 11.50 & +2.68 & 7.5 & -7.0 & 71.8 & +8.8 & 3976 \\
\hline $\begin{array}{l}\text { Background } \\
+\operatorname{ash}_{\mathrm{s}} 5.0 \mathrm{t} / \mathrm{ha}\end{array}$ & 17.1 & +63.0 & 11.00 & -1.79 & 7.0 & -7.5 & 84.3 & +21.3 & 3674 \\
\hline 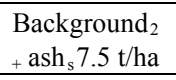 & 17.2 & +63.0 & 10.70 & -4.46 & 8.5 & -6.0 & 67.5 & +4.5 & 2992 \\
\hline $\mathrm{HCP}_{0.5}$ & 1.2 & & & $0.67 \%$ & & & & $8.22 \%$ & \\
\hline
\end{tabular}


Table 1. Continued

\begin{tabular}{|c|c|c|c|c|c|c|c|c|c|}
\hline \multicolumn{10}{|c|}{2017} \\
\hline $\begin{array}{c}\text { No fertilizers } \\
\text { - control }\end{array}$ & 9.3 & - & 10.6 & - & 2.7 & - & 95.6 & - & - \\
\hline $\begin{array}{c}\mathrm{NPK})_{120}- \\
\text { economic } \\
\text { control }\end{array}$ & 23.2 & - & 10.7 & - & 3.7 & - & 94.7 & - & - \\
\hline $\begin{array}{l}\text { Background }_{1} \\
-(\mathrm{NPK})_{90}\end{array}$ & 22.7 & - & 10.3 & - & 3.9 & - & 87.4 & - & - \\
\hline $\begin{array}{l}\text { Background }_{1} \\
+\operatorname{ash}_{\mathrm{s}} 2.5 \mathrm{t} / \mathrm{ha}\end{array}$ & 23.3 & +2.6 & 11.1 & +7.8 & 3.2 & -17.9 & 92.1 & 4.7 & - \\
\hline $\begin{array}{l}\text { Background }_{1} \\
+\operatorname{ash}_{\mathrm{s}} 5 \mathrm{t} / \mathrm{ha}\end{array}$ & 23.1 & +1.8 & 11.0 & +6.8 & 3.5 & -10.3 & 89.0 & 1.6 & - \\
\hline $\begin{array}{l}\text { Background }_{1} \\
+\operatorname{ash}_{\mathrm{b}} 2.5 \mathrm{t} / \mathrm{ha}\end{array}$ & 24.2 & +6.6 & 11.0 & +6.8 & 3.6 & -7.7 & 92.4 & 5.0 & 504 \\
\hline $\begin{array}{c}\begin{array}{c}\text { Background }_{1} \\
+ \text { ash }_{\mathrm{b}} 5 \mathrm{t} / \mathrm{ha}\end{array} \\
\end{array}$ & 26.9 & +18.5 & 11.0 & +6.8 & 3.7 & -5.1 & 94.1 & 6.7 & 1792 \\
\hline $\mathrm{Ash}_{\mathrm{s}} 2.5 \mathrm{t} / \mathrm{ha}$ & 10.5 & 12.9 & 10.6 & - & 5.0 & - & 94.1 & 6.7 & - \\
\hline $\operatorname{Ash}_{\mathrm{s}} 5 \mathrm{t} / \mathrm{ha}$ & 8.4 & $\begin{array}{l}-9.7 \\
\end{array}$ & 10.2 & - & 3.7 & - & 91.0 & 3.6 & - \\
\hline $\begin{array}{c}\text { Background }_{2} \\
-(\mathrm{NPK})_{60}\end{array}$ & 21.8 & - & 10.5 & - & 1.8 & - & 93.2 & & - \\
\hline $\begin{array}{l}\text { Background }_{2} \\
+\operatorname{ash}_{\mathrm{s}} 2.5 \mathrm{t} / \mathrm{ha}\end{array}$ & 22.1 & +1.4 & 10.7 & +1.9 & 4.3 & +139 & 93.7 & 0.5 & - \\
\hline $\begin{array}{l}\text { Background }_{2} \\
+\operatorname{ash}_{\mathrm{s}} 5 \mathrm{t} / \mathrm{ha}\end{array}$ & 22.5 & +3.2 & 10.7 & +1.9 & 2.4 & +33.3 & 93.6 & 0.4 & - \\
\hline $\begin{array}{l}\text { Background }_{2} \\
+\operatorname{ash}_{\mathrm{b}} 2.5 \mathrm{t} / \mathrm{ha}\end{array}$ & 23.7 & +8.7 & 10.7 & +1.9 & 2.3 & +27.8 & 94.8 & 1.6 & - \\
\hline $\begin{array}{c}\text { Background }_{2} \\
+ \text { ash }_{\mathrm{b}} 5 \mathrm{t} / \mathrm{ha}\end{array}$ & 22.1 & +1.4 & 10.7 & +1.9 & 3.3 & +83.3 & 94.7 & 1.5 & - \\
\hline $\mathrm{HCP}_{0.5}$ & 1.4 & & & $0.70 \%$ & & & & $4.22 \%$ & \\
\hline \multicolumn{10}{|c|}{2018} \\
\hline $\begin{array}{l}\text { No fertilizers } \\
- \text { control } \\
\end{array}$ & 9.8 & - & 9.7 & - & 3.0 & - & - & - & - \\
\hline $\begin{array}{c}(\mathrm{NPK})_{120-} \\
\text { economic } \\
\text { control }\end{array}$ & 17.7 & - & 9.9 & - & 5.4 & - & - & - & - \\
\hline $\begin{array}{c}\text { Background }_{1} \\
-(\mathrm{NPK})_{90} \\
\end{array}$ & 16.8 & - & 9.9 & - & 6.8 & - & - & - & - \\
\hline $\begin{array}{l}\text { Background }_{1} \\
+\operatorname{ash}_{\mathrm{s}} 2.5 \mathrm{t} / \mathrm{ha}\end{array}$ & 19.5 & 16.1 & 10.2 & +3.0 & 6.4 & -5.9 & - & - & 1414 \\
\hline $\begin{array}{l}\text { Background } \\
+\operatorname{ash}_{\mathrm{s}} 5 \mathrm{t} / \mathrm{ha} \\
\end{array}$ & 18.9 & 12.5 & 10.6 & +7.1 & 5.3 & -22.1 & - & - & 202 \\
\hline $\begin{array}{l}\text { Background }_{1} \\
+\operatorname{ash}_{\mathrm{b}} 2.5 \mathrm{t} / \mathrm{ha}\end{array}$ & 20.2 & 20.2 & 10.3 & +4.0 & 4.6 & -32.4 & - & - & 1944 \\
\hline $\begin{array}{l}\text { Background }_{1} \\
{ }_{+} \text {ash }_{\mathrm{b}} 5 \mathrm{t} / \mathrm{ha}\end{array}$ & 21.9 & 30.4 & 10.1 & +2.0 & 3.8 & -44.1 & - & - & 2474 \\
\hline $\mathrm{Ash}_{\mathrm{s}} 2.5 \mathrm{t} / \mathrm{ha}$ & 11,0 & 12,2 & 9.6 & -1.0 & 8.7 & 190.0 & - & - & - \\
\hline $\mathrm{Ash}_{\mathrm{s}} 5 \mathrm{t} / \mathrm{ha}$ & 11,8 & 20,4 & 10.4 & +7.2 & 5.5 & 83.3 & - & - & - \\
\hline $\mathrm{Ash}_{\mathrm{b}} 2.5 \mathrm{t} / \mathrm{ha}$ & 11,4 & 16,3 & 10.3 & +6.2 & 3.5 & 16.7 & - & - & - \\
\hline $\mathrm{Ash}_{\mathrm{b}} 5 \mathrm{t} / \mathrm{ha}$ & 12.6 & 28.6 & 10.2 & +5.2 & 2.8 & -6.7 & - & - & - \\
\hline $\begin{array}{c}\text { Background }_{2} \\
-(\mathrm{NPK})_{60}\end{array}$ & 13.7 & - & 10.2 & - & 2.1 & & - & - & - \\
\hline $\begin{array}{l}\text { Background }_{2} \\
+\operatorname{ash}_{\mathrm{s}} 2.5 \mathrm{t} / \mathrm{ha}\end{array}$ & 15.6 & 13.9 & 10.3 & +1.0 & 3.8 & 81.0 & - & - & 808 \\
\hline $\begin{array}{l}\text { Background }_{2} \\
+\operatorname{ash}_{\mathrm{s}} 5 \mathrm{t} / \mathrm{ha} \\
\end{array}$ & 17.2 & 25.5 & 10.6 & +4.0 & 2.2 & 4.8 & - & - & 1262 \\
\hline $\begin{array}{l}\text { Background }_{2} \\
+\operatorname{ash}_{\mathrm{b}} 2.5 \mathrm{t} / \mathrm{ha}\end{array}$ & 17.4 & 27.0 & 10.3 & +1.0 & 3.5 & 66.7 & - & - & 2171 \\
\hline $\begin{array}{c}\text { Background }_{2} \\
+\operatorname{ash}_{\mathrm{b}} 5 \mathrm{t} / \mathrm{ha}\end{array}$ & 17.9 & 30.7 & 10.2 & +0.0 & 4.2 & 100.0 & - & - & 1792 \\
\hline $\mathrm{HCP}_{0.5}$ & 1.2 & & & $0.67 \%$ & & & & & \\
\hline
\end{tabular}

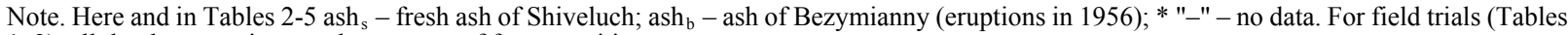
$1,2)$, all the data are given as the average of four repetitions. 
In 2018, the increase in yield for different variants of the experiment ranged $14-31 \%$. The best effect of the ash of the Bezymianny volcano on the potato yield was again confirmed. When volcanic ash was used without mineral fertilizers, the yield increase relative to the background was also significant $-16-29 \%$. However, the absolute value of the yield in this variant was low, 1.1-1.3 t/ha.

Besides increasing the yield, the quality of keeping potatoes is improved. For the 2014 harvest, the statistically significant number of healthy potato tubers by the spring of next year increased (relative to the background) by $8.8-21.3 \%$, and for the 2017 experiment by $4.7-6.7 \%$.

At a mineral fertilizers dose $(\mathrm{NPK})_{60}$ in 2014 and $(\mathrm{NPK})_{90}$ in 2017 and 2018, the use of ash reduces tuber lesion by Rhizoctonia (Table 1). In all the years of the experiment, all variants of experiments with ash show a significant increase in starch in potato tubers (Table 1).

In the experiment with timothy in 2015 (ash from the
Bezymianny volcano and no mineral fertilizers), statistically significant increases in yield relative to the background were obtained: with the maximum ash dose of $5 \mathrm{t} / \mathrm{ha}$ by $29.4 \%$, and with $2.5 \mathrm{t} / \mathrm{ha}$ by $23.5 \%$ (Table 2 ). Similar introduction of only fresh volcanic ash from the Shiveluch volcano into the soil did not have significant positive effect. Notably (as in the experiment with potatoes) in all the variants with volcanic ash alone, the absolute yield of timothy was also rather low - up to 8.8 t/ha. At the same time, productivity in the variants with ash + mineral fertilizer reached $24.73 \mathrm{t} / \mathrm{ha}$. Therefore, using the studied volcanic ash without the traditional mineral fertilizers cannot be considered as an effective method of increasing yields in agriculture.

When the ash of both volcanoes was added to the soil in combination with mineral fertilizers at the dose of $\mathrm{N}_{90} \mathrm{P}_{90} \mathrm{~K}_{90}$, the yield of timothy increased significantly relative to the background - $29-50 \%$ (Bezymianny) and 21-27\% (Shiveluch) (Table 2).

Table 2. Effectiveness of the use of volcanic ash in the cultivation of timothy in 2015

\begin{tabular}{|c|c|c|c|c|}
\hline Experiment variant & Yield, t/ha & \pm to the background, $\mathrm{t} / \mathrm{ha}$ & $\begin{array}{c} \pm \text { to the } \\
\text { background, \% }\end{array}$ & $\begin{array}{c}\text { Economic efficiency, } \\
\text { USD/ha }\end{array}$ \\
\hline No fertilizers - control & 6.8 & - & - & - \\
\hline $\mathrm{Ash}_{\mathrm{b}} 2.5 \mathrm{t} / \mathrm{ha}$ & 8.4 & 1.6 & 23.5 & - \\
\hline $\mathrm{Ash}_{\mathrm{b}} 5.0 \mathrm{t} / \mathrm{ha}$ & 8.8 & 2.0 & 29.4 & - \\
\hline $\mathrm{Ash}_{\mathrm{s}} 2.5 \mathrm{t} / \mathrm{ha}$ & 7.0 & 0.2 & 2.9 & - \\
\hline $\mathrm{Ash}_{\mathrm{s}} 5.0 \mathrm{t} / \mathrm{ha}$ & 6.8 & 0.0 & 1.0 & - \\
\hline \multicolumn{2}{|l|}{$\mathrm{HCP}_{05}$} & \multicolumn{2}{|c|}{$1.85 \mathrm{t} / \mathrm{ha}$} & \\
\hline Background $-(\mathrm{NPK})_{90}$ & 16.5 & & & - \\
\hline Background $+\operatorname{ash}_{b} 2.5 \mathrm{t} / \mathrm{ha}$ & 21.3 & 4.8 & 29.0 & 1599 \\
\hline Background $_{+} \operatorname{ash}_{b} 5.0 \mathrm{t} / \mathrm{ha}$ & 24.7 & 8.2 & 49.6 & 2510 \\
\hline Background $_{+} \operatorname{ash}_{\mathrm{s}} 2.5 \mathrm{t} / \mathrm{ha}$ & 20.9 & 4.4 & 26.6 & 1402 \\
\hline Background $_{+} \operatorname{ash}_{\mathrm{s}} 5.0 \mathrm{t} / \mathrm{ha}$ & 20.0 & 3.5 & 21.4 & 203 \\
\hline \multicolumn{2}{|l|}{$\mathrm{HCP}_{05}$} & \multicolumn{2}{|c|}{$2.03 \mathrm{t} / \mathrm{ha}$} & \\
\hline
\end{tabular}

\section{Production experience}

The 2016 production experience on the use of ash with mineral fertilizers dose of $\mathrm{N}_{90} \mathrm{P}_{90} \mathrm{~K}_{90}$ on the annual forage grasses field increased its yield by $32.2 \%$ (Table 3, Figure 1). In the green mass of grasses, an increase content of total nitrogen (by 25.8\%), phosphorus (by 50\%), and crude protein (by 12\%) in relation to the background was observed (Table 3). 


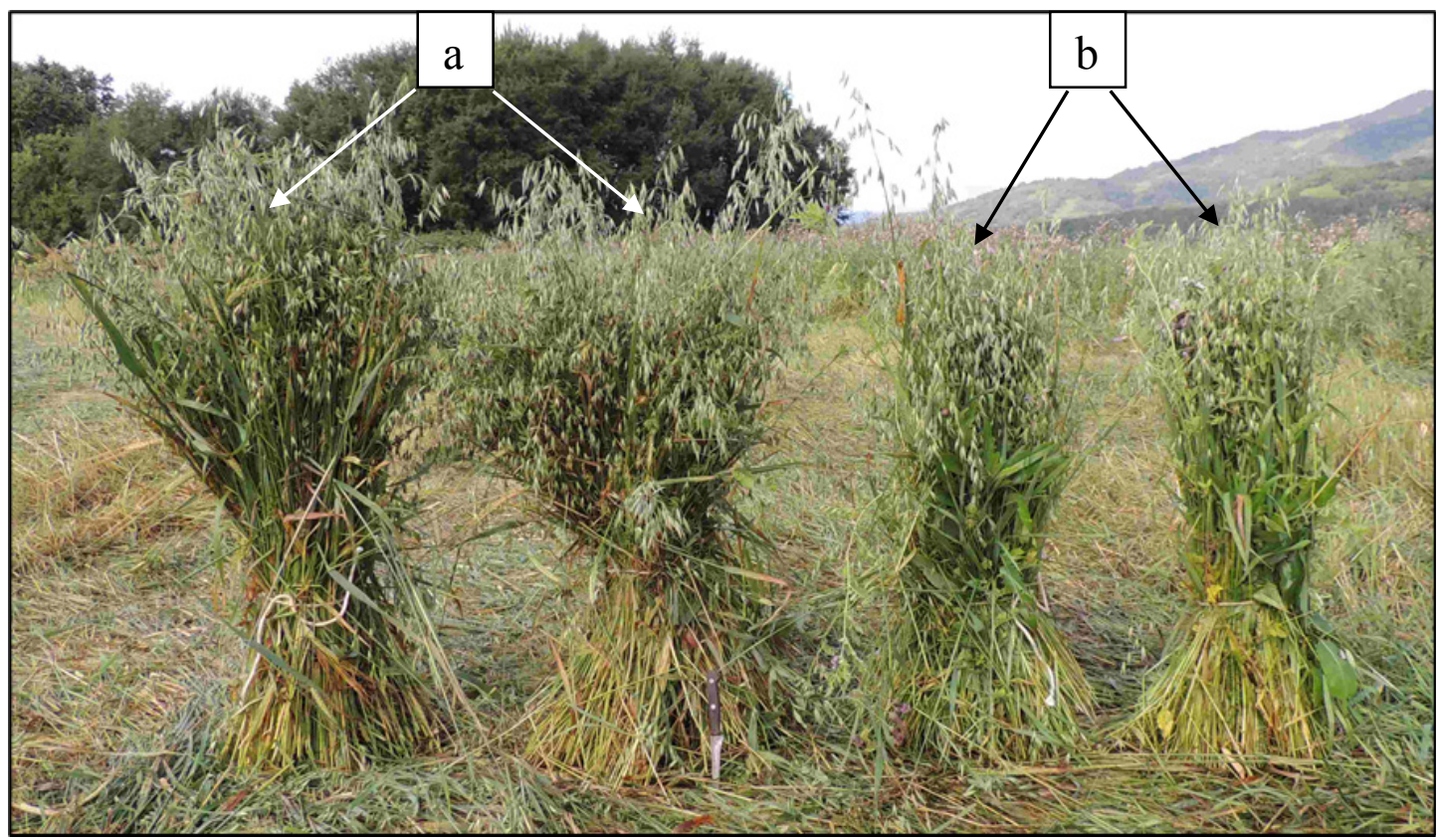

Figure 1. Samples from the experimental field of annual forage grasses, cut from an area of $4 \mathrm{~m}^{2}$, grown: (a) - using volcanic ash; (b) - without the use of ash

Table 3. Influence of mineral fertilizers and ash of the Shiveluch volcano on the yield and quality of green mass of annual forage grasses (manufacturing experiment of 2016)

\begin{tabular}{|c|c|c|c|}
\hline \multirow{2}{*}{\multicolumn{2}{|c|}{$\begin{array}{l}\text { Indicators of yield and quality of } \\
\text { forage grasses }\end{array}$}} & \multicolumn{2}{|c|}{ Experiment variants } \\
\hline & & \multirow{2}{*}{$\begin{array}{c}\begin{array}{c}\text { Backgrou } \\
\text { nd - } \\
(\mathbf{N P K})_{90}\end{array} \\
15.6\end{array}$} & \multirow{2}{*}{$\begin{array}{c}\begin{array}{c}\text { Background } \\
\text { +ash }_{\mathbf{s}}-\mathbf{2} \text { t/ha }\end{array} \\
19.5\end{array}$} \\
\hline \multirow[b]{2}{*}{ Yield, t/ha } & $\mathrm{t} / \mathrm{ha}$ & & \\
\hline & $\begin{array}{c} \pm \text { to the } \\
\text { background, \% }\end{array}$ & - & 32.2 \\
\hline \multirow{2}{*}{$\begin{array}{l}\text { Nitrogen } \\
\text { content }\end{array}$} & $\%$ & 9.02 & 11.35 \\
\hline & $\begin{array}{c} \pm \text { to the } \\
\text { background, \% }\end{array}$ & - & 25.8 \\
\hline \multirow{2}{*}{$\begin{array}{l}\text { Phosphorus } \\
\text { content }\end{array}$} & $\%$ & 0.08 & 0.12 \\
\hline & $\begin{array}{c} \pm \text { to the } \\
\text { background, \% }\end{array}$ & - & 50.0 \\
\hline \multirow{2}{*}{$\begin{array}{l}\text { Crude protein } \\
\text { content }\end{array}$} & $\%$ & 3.9 & 4.37 \\
\hline & $\begin{array}{c} \pm \text { to the } \\
\text { background, \% }\end{array}$ & - & 12.0 \\
\hline \multicolumn{2}{|c|}{ Economic efficiency, USD/ha } & - & 2976 \\
\hline
\end{tabular}

\section{Discussion}

Increased productivity of agrocenoses during experiments in 2014-2018 on the use of volcanic ash in agriculture could be related with two possible factors: improvement of the physical properties of soils due to the intake of additional mineral substances; changes in the chemical composition of the soils due to the introduction of volcanic ash.

The introduction of ash did not have any no effect on improving the physical properties of soils with a mechanical composition (sandy loam) close to the composition of the applied ashes. The water-holding capacity of the soils, depending on its granular and mineral composition can not change on the humus content,structural condition porosity and density when applying fresh ash,either. The latter is not able to significantly change the listed indicators of volcanic soils that are already loose, porous, with a high water-holding but low water-carrying capacity, always containing more or less volcanic ash from older eruptions.

The results obtained reveal increased bioproductivity of soils due to a change in their chemical composition when ash is applied. After the harvesting of potatoes with the plotting experiment in 2014, despite the associated natural removal of nutrients from the soil, ashes in most variants led to an increase in mobile phosphorus by $7-21 \%$ and mobile potassium by $16-77 \%$ (Table 4). Besides in comparison with the background, the following was observed: decreased hydrolytic acidity, increased sum of exchangeable bases and, accordingly, increased soil saturation with bases at virtually unchanged $\mathrm{pH}$ (Table 4). In the production experience of using ashes on annual forage grasses, similar changes in the discussed parameters were observed, and the increase in mobile phosphorus reached $140 \%$. 
Table 4. Changes in soil properties due to the introduction of volcanic ash in the cultivation of potatoes in 2014 and of forage grasses in 2016

\begin{tabular}{|c|c|c|c|c|c|c|c|c|c|c|}
\hline \multirow{3}{*}{ Experiment variant } & \multirow{3}{*}{$\begin{array}{c}\text { pH } \\
\text { water }\end{array}$} & \multirow{3}{*}{$\begin{array}{l}\text { pH } \\
\text { salt }\end{array}$} & \multirow[b]{2}{*}{$\begin{array}{l}\text { Hydrolytic } \\
\text { acidity }\end{array}$} & \multirow{3}{*}{$\begin{array}{c}\text { Amou } \\
\text { nt of } \\
\text { excha } \\
\text { ngeabl } \\
\text { e bases } \\
\text { os. dry }\end{array}$} & \multirow{2}{*}{\multicolumn{2}{|c|}{$\begin{array}{c}\text { Degree of } \\
\text { saturation of } \\
\text { soils with bases }\end{array}$}} & \multicolumn{2}{|c|}{$\mathbf{P}_{2} \mathbf{O}_{5}$} & \multicolumn{2}{|c|}{$\mathbf{K}_{2} \mathrm{O}$} \\
\hline & & & & & & & \multicolumn{4}{|c|}{ mobile (the Kirsanov reaction) } \\
\hline & & & $\begin{array}{c}\mathrm{mEq} / 100 \mathrm{~g} \text { abs. dry } \\
\text { soil }\end{array}$ & & $\%$ &, $\pm \% *$ & $\mathrm{mg} / \mathrm{kg}$ &, $\pm \%$ & $\mathrm{mg} / \mathrm{kg}$ &, $\pm \%$ \\
\hline \multicolumn{11}{|c|}{2014} \\
\hline No fertilizers - control & 4.9 & 5.4 & 3.26 & 4.07 & 55.53 & - & 164.3 & - & 103.8 & - \\
\hline Background $_{1-} \mathrm{N}_{120} \mathrm{P}_{120} \mathrm{~K}_{120}$ & 4.7 & 5.6 & 4.14 & 3.13 & 43.1 & - & 179.9 & - & 150.0 & \\
\hline Background $_{1+} \operatorname{ash}_{\mathrm{s}} 2.5 \mathrm{t} / \mathrm{ha}$ & 4.7 & 5.7 & 3.26 & 4.07 & 55.5 & +12.4 & 173.6 & -3.5 & 204.4 & +36.3 \\
\hline Background $_{1+} \operatorname{ash}_{\mathrm{s}} 5.0 \mathrm{t} / \mathrm{ha}$ & 4.6 & 5.2 & 3.87 & 8.7 & 69.2 & +26.2 & 217.8 & +21.1 & 230.4 & +53.6 \\
\hline Background $_{1+} \operatorname{ash}_{\mathrm{s}} 7.5 \mathrm{t} / \mathrm{ha}$ & 4.6 & 5.2 & 3.96 & 9.10 & 69.7 & +26.6 & 206.6 & +14.8 & 265.2 & +76.8 \\
\hline Background $_{2-} \mathrm{N}_{60} \mathrm{P}_{60} \mathrm{~K}_{60}$ & 4.6 & 5.2 & 3.96 & 4.65 & 54.0 & - & 157.0 & - & 123.1 & - \\
\hline Background $_{2+} \operatorname{ash}_{\mathrm{s}} 2.5 \mathrm{t} / \mathrm{ha}$ & 4.7 & 5.7 & 3.56 & 5.10 & 58.9 & +4.9 & 174.8 & +11.3 & 175.0 & +42.2 \\
\hline Background $_{2+} \operatorname{ash}_{\mathrm{s}} 5.0 \mathrm{t} / \mathrm{ha}$ & 4.9 & 5.2 & 3.12 & 7.10 & 63.3 & +9.3 & 167.8 & +6.9 & 158.3 & +28.6 \\
\hline Background $_{2+} \operatorname{ash}_{\mathrm{s}} 7.5 \mathrm{t} / \mathrm{ha}$ & 4.7 & 5.7 & 3.05 & 6.90 & 69.3 & +15.3 & 137.5 & -12.4 & 142.3 & +15.6 \\
\hline \multicolumn{11}{|c|}{2016} \\
\hline Background $-\mathrm{N}_{90} \mathrm{P}_{90} \mathrm{~K}_{90}$ & 4.0 & 4.3 & 22.55 & 3.13 & 12.2 & - & 112.5 & - & 115.0 & - \\
\hline 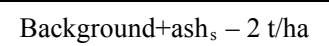 & 4.1 & 4.3 & 28.30 & 8.76 & 23.6 & +11.4 & 270.5 & +140 & 167.0 & +45.2 \\
\hline
\end{tabular}

Note. * ", $\pm \% "$ - relative to the background 


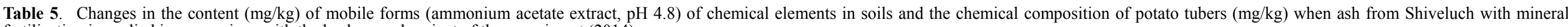
fertilization is applied in comparison with the background variant of the experiment (2014)

\begin{tabular}{|c|c|c|c|c|c|c|c|c|c|c|c|c|c|}
\hline \multirow[b]{2}{*}{ Elements } & \multicolumn{3}{|c|}{ Soil } & \multicolumn{3}{|c|}{ Potato tubers } & \multirow[b]{2}{*}{ Elements } & \multicolumn{3}{|c|}{ Soil } & \multicolumn{3}{|c|}{ Potato tubers } \\
\hline & $\begin{array}{c}\text { Background } \\
\mathbf{N}_{60} \mathrm{P}_{60} \mathrm{~K}_{60}\end{array}$ & 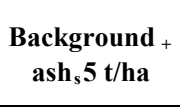 &, $\pm \% *$ & $\begin{array}{c}\text { Background } \\
\mathbf{N}_{60} P_{60} K_{60}\end{array}$ & $\begin{array}{c}\text { Background } \\
+ \text { ash }_{\mathrm{s}} \\
5 \mathrm{t} / \mathrm{ha} \\
\end{array}$ &, $\pm \% *$ & & \begin{tabular}{|c} 
Background \\
$\mathbf{N}_{60} P_{60} K_{60}$
\end{tabular} & $\begin{array}{c}\text { Background }+ \\
\text { ash }_{\mathrm{s}} \\
5 \mathrm{t} / \mathrm{ha}\end{array}$ &, $\pm \% *$ & $\begin{array}{c}\text { Background } \\
\mathrm{N}_{60} \mathrm{P}_{60} \mathrm{~K}_{60}\end{array}$ & $\begin{array}{c}\text { Background }+ \\
\text { ash }_{\mathbf{s}} \\
5 \mathrm{t} / \mathrm{ha}\end{array}$ &, $\pm \% *$ \\
\hline $\mathrm{Li}$ & _** & - & - & 0.011 & 0.011 & 0.0 & $\mathrm{Cd}$ & 0.04 & 0.04 & +13.9 & 0.025 & 0.020 & -20.0 \\
\hline $\mathrm{Be}$ & 0.031 & 0.026 & -16.1 & - & - & - & $\mathrm{Sn}$ & - & - & - & 0.054 & 0.047 & -13.0 \\
\hline $\mathrm{B}$ & - & - & - & 8 & 6.9 & -13.8 & $\mathrm{Sb}$ & - & - & - & 0.004 & 0.003 & -17.9 \\
\hline $\mathrm{Na}$ & 23 & 21 & -8.7 & 38 & 33 & -13.2 & $\mathrm{Cs}$ & 0.031 & 0.034 & -8.8 & 0.04 & 0.02 & -35.1 \\
\hline $\mathrm{Mg}$ & 21 & 18 & -14.3 & 1100 & 870 & -20.9 & $\mathrm{Ba}$ & 21 & 18 & -14.3 & 1.5 & 1.2 & -20.0 \\
\hline $\mathrm{Al}$ & 950 & 800 & -15.8 & 130 & 140 & +7.7 & $\mathrm{La}$ & 0.260 & 0.260 & 0.0 & 0.0098 & 0.0082 & -16.3 \\
\hline $\mathrm{Si}$ & 110 & 90 & -18.2 & 89 & 69 & -22.5 & $\mathrm{Ce}$ & 0.450 & 0.450 & 0.0 & 0.0180 & 0.0160 & -11.1 \\
\hline $\mathrm{P}$ & 16 & 19 & 18.8 & 1500 & 1200 & -20.0 & $\operatorname{Pr}$ & 0.065 & 0.065 & 0.0 & - & - & - \\
\hline $\mathrm{S}$ & 55 & 66 & +20.0 & 1900 & 1300 & -31.6 & $\mathrm{Nd}$ & 0.280 & 0.280 & 0.0 & 0.0096 & 0.0074 & -22.9 \\
\hline $\mathrm{K}$ & 210 & 200 & -4.8 & 23000 & 19000 & -17.4 & $\mathrm{Sm}$ & 0.080 & 0.078 & -2.5 & - & - & - \\
\hline $\mathrm{Ca}$ & 800 & 600 & -25.0 & 130 & 130 & 0.0 & $\mathrm{Eu}$ & 0.019 & 0.019 & 0.0 & 0.0009 & 0.0008 & -4.7 \\
\hline $\mathrm{Ti}$ & 0.92 & 0.80 & -13.0 & 2.7 & 2.7 & 0.0 & $\mathrm{Gd}$ & 0.085 & 0.084 & -1.2 & 0.0026 & 0.0022 & -15.4 \\
\hline $\mathrm{V}$ & 0.11 & 0.11 & 0.0 & 0.14 & 0.14 & 0.0 & $\mathrm{~Tb}$ & 0.012 & 0.012 & 0.0 & - & - & - \\
\hline $\mathrm{Cr}$ & 0.13 & 0.10 & -23.0 & 0.34 & 0.29 & -14.7 & Dy & 0.059 & 0.056 & -5.1 & 0.0026 & 0.0021 & -19.2 \\
\hline $\mathrm{Mn}$ & 17 & 22 & +29.4 & 15 & 14 & -6.7 & Ho & 0.014 & 0.014 & 0.0 & - & - & - \\
\hline $\mathrm{Fe}$ & 68 & 67 & -1.5 & 46 & 41 & -10.9 & Er & 0.038 & 0.037 & -2.6 & 0.0016 & 0.0017 & 6.2 \\
\hline Co & 0.091 & 0.120 & +31.9 & 0.1 & 0.087 & -13.0 & $\mathrm{Tm}$ & 0.0043 & 0.0043 & 0.0 & - & - & - \\
\hline $\mathrm{Ni}$ & 0.25 & 0.25 & 0.0 & 0.53 & 0.33 & -37.7 & $\mathrm{Yb}$ & 0.027 & 0.027 & 0.0 & 0.0015 & 0.0013 & -13.3 \\
\hline $\mathrm{Cu}$ & 0.91 & 0.98 & +7.7 & 4.6 & 3.3 & -28.3 & $\mathrm{Lu}$ & 0.0037 & 0.0038 & -2.6 & - & - & - \\
\hline $\mathrm{Zn}$ & 2.6 & 3.2 & +23.1 & 12 & 8.5 & -29.2 & $\mathrm{Hf}$ & 0.013 & 0.011 & -15.4 & 0.0024 & 0.0017 & -29.2 \\
\hline $\mathrm{Ga}$ & 0.03 & 0.028 & -6.7 & 0.034 & 0.031 & -8.8 & $\mathrm{Ta}$ & - & - & - & 0.0022 & 0.0011 & -50.0 \\
\hline $\mathrm{Se}$ & - & - & - & 0.049 & 0.054 & 10.2 & $\mathrm{~W}$ & - & - & - & 0.0120 & 0.0074 & -38.3 \\
\hline $\mathrm{Rb}$ & 0.25 & 0.24 & -4.0 & 10 & 6.8 & -32.0 & $\mathrm{Hg}$ & - & - & - & 0.0180 & 0.0140 & -22.2 \\
\hline $\mathrm{Sr}$ & 4.7 & 4.3 & -8.5 & 0.95 & 0.085 & -91.1 & $\mathrm{Tl}$ & 0.014 & 0.013 & -7.1 & 0.0076 & 0.0057 & -25.0 \\
\hline $\mathrm{Y}$ & 0.39 & 0.39 & 0.0 & 0.014 & 0.011 & -21.4 & $\mathrm{~Pb}$ & 0.083 & 0.083 & 0.0 & 0.0780 & 0.0750 & -3.8 \\
\hline $\mathrm{Zr}$ & 0.33 & 0.27 & -18.2 & 0.049 & 0.041 & -16.3 & $\mathrm{Bi}$ & 0.0008 & 0.0009 & -11.0 & - & - & - \\
\hline $\mathrm{Nb}$ & - & - & - & 0.0027 & 0.018 & -33.3 & Th & 0.017 & 0.017 & 0.0 & 0.0020 & 0.0012 & -40.0 \\
\hline Mo & - & - & - & 0.14 & 0.14 & 0.0 & $\mathrm{U}$ & 0.039 & 0.036 & -7.7 & 0.0018 & 0.0012 & -33.3 \\
\hline
\end{tabular}

Note. * ", $\pm \% "$ - relative to the background; ** "-" - content in both variants of the experiment is below the detection limit of the analysis. 
In the soils after harvest in the experiment variables with ash, the content of the following movable shapes increased, relative to the background: Co (32\%), Mn (29\%), S (20\%), Zn (23\%) and $\mathrm{Cu}(8 \%)$ (Table 5).

Starch in potato tubers, resistance to diseases and keeping quality increased, and infestation with Rhizoctonia decreased (Table 1).

A similar effect with the introduction of ash was noted in the vegetation experiment with corn at Kuban Agrarian University [28]. Besides increased growth in the boot stage, increased weight of the leafy mass and increased volume of the root system, applying ash led to increased mineral nitrogen consumption (by 20-36\%) and phosphorus consumption (by 25-43\%) from vegetation vessels.

In general, introducing volcanic ash into the soil does not increase the concentration of chemical elements in potato tubers (Table 5). On the contrary, the contents of most of them decrease relative to the background due to an increase in the yield and the associated absorption of chemical elements from the soil by a larger amount of biomass.

According to the sanitary and epidemiological rules and norms 2.3.2.1078-01, the permissible levels of toxic elements in a given mass (volume) of fresh potatoes are $(\mathrm{mg} / \mathrm{kg}): \mathrm{Pb}-0.5, \mathrm{As}-0.2, \mathrm{Cd}-0.03, \mathrm{Hg}-0.02$. The concentrations of these elements in potatoes in the described experiment with the introduction of volcanic ash into soils are (background/with ash, $\mathrm{mg} / \mathrm{kg}$ ): $\mathrm{Pb}-$ $0.078 / 0.075$, As $-<0.01 /<0.01, \mathrm{Cd}-0.025 / 0.020, \mathrm{Hg}-$ $0.018 / 0.014$ (Table 6). Thus, the contents of food toxic elements in the studied potatoes, both in the background variant and in the variant with the addition of volcanic ash, do not exceed the established standards.

To evaluate the economic efficiency of using volcanic ash in the cultivation of agricultural crops, following formula was used:

$\mathrm{E}=\left(\mathrm{C}_{\mathrm{b}}-\mathrm{C}_{\mathrm{n}}\right)+\left(\mathrm{P}_{\mathrm{n}}-\mathrm{P}_{\mathrm{b}}\right) \times \mathrm{n}$; where где $\mathrm{C}_{\mathrm{b}}, \mathrm{C}_{\mathrm{n}}$ are production costs (USD/ha) in the basic and new versions; $\mathrm{P}_{\mathrm{n}}, \mathrm{P}_{\mathrm{b}}$ - production costs (USD/ha) in the basic and new versions; $\mathrm{n}$-planting area, 1 ha. The calculations used the following characteristics: basic costs for growing 1 ha: potatoes at $(\mathrm{NPK})_{120}-11.8$ thousand USD, at $(\mathrm{NPK})_{60}-$ 11.6 thousand USD; annual grasses at (NPK) $)_{90}-748.8$ USD; perennial grasses at $(\mathrm{NPK})_{90}-540.7$ USD; additional costs for the introduction of 1 ton of volcanic ash are USD 303. The costs of gross production of 1 ton are: potatoes - 757.6 USD; annual grasses - 607.6 USD; perennial grasses -490.9 USD.

The analysis of the data obtained revealed that a significant economic effect (3.0 thousand USD/ha) can be obtained from the cultivation of annual forage grasses with the introduction of volcanic ash at the dose of $2 \mathrm{t} / \mathrm{ha}$ against the background of the traditional (for the region) dose of mineral fertilizers ((NPK)90 (Table 3). In the experiment of perennial forage grasses, the highest economic effect was established for the variants with the ash from the Bezymianny volcano at the doses of 2.5 and $5.0 \mathrm{t} / \mathrm{ha}$ (1.6 and 2.5 thousand USD/ha, respectively) against the background of mineral fertilizers also at the dose (NPK) $)_{90}$ (Table 2).

Differences in the economic efficiency of using ash in potato cultivation are obviously due to significant differences in climatic indicators for 2014-2018 (Table 1). The lowest economic efficiency was established for 2018 - the most favorable year, rare for the region in terms of climatic conditions. In 2018, the potato yield was the highest, and the increase in yield and, accordingly, in the economic efficiency from introducing ash was the smallest. A significant economic benefit (1.8 thousand USD/ha) under such climatic conditions can be obtained only by applying ash from Bezymianny at the dose of 5 t/ha against the background of a reduced (relatively traditional) dose of mineral fertilizers. In 2014, when the sum of active temperatures was also higher than the long-term average, but precipitation for the summer-autumn period was below the average long-term value, the economic efficiency of the new method, even from the use of less productive ash from Shiveluch, was the most significant for all the years of experience and amounted to 3.98 and 3.67 thousand USD/ha with ash application at the doses of 2.5 and 5.0. t/ha, respectively. Positive results obtained in land and production experiments on the introduction of volcanic ash from Kamchatka into soils when growing potatoes and forage grasses allow to consider volcanic ashes as a potential source of improving soil bioproductivity and recommending them for agricultural use. A patent was obtained with a formula for improving the diet of plants including the introduction of volcanic ash into the soil using mineral fertilizers (Zakharikhina and Litvinenko 2017).

\section{Conclusion}

The introduction of volcanic ash into the soil with the obligatory use of mineral fertilizers increases the productivity of agricultural crops. The positive effect of fertilizers is increased as well, and product quality is improved, expressed in increased crude protein also in annual forage grasses, increased starch content in potato tubers, and better resistance to potato diseases.

Under any climatic conditions, introducing volcanic products of Bezymianny into soils against the background of a reduced (relatively traditional) dose of mineral fertilizers for potatoes and traditional for forage grasses yields a significant economic effect $(1.6-3.0$ thousand $\mathrm{USD} / \mathrm{ha}$ for grasses and $1.8-4.0$ thousand USD/ha for potatoes).

Positive results obtained in land and production experiments on the introduction of volcanic ash from 
Kamchatka into soils when growing potatoes and forage grasses allow to consider volcanic ashes as a potential source of improving soil bioproductivity and recommending them for agricultural use. A patent was obtained with a formula for improving the diet of plants including the introduction of volcanic ash into the soil using mineral fertilizers [29].

\section{Declaration of Interest Statement}

The authors declare that they have no competing interests

\section{REFERENCES}

[1] Benkova M, Nenova L, Simeonova T, Atanassova I., "The effect of Fluvisol applied biochar on wheat yield and nutrient uptake", Bulgarian Journal of Agricultural Science, vol. 26(1), pp. 84-90, 2020.

[2] Mahmoud AWM, Asmaa BESE, Sanaa EAE, Hoda S., "Boosting biochemical composition of stevia plant using biochar loaded with beneficial microorganism strains", Bulgarian Journal of Agricultural Science, vol. 26(4), pp. 748-760. 2020.

[3] Suhaimi F, Adibah F, Jahan S, Nudin-Nur-Fatihah H., "Betaine-rich Nano fertilizer improves growth parameters of Zea mays var. Saccharata and Arabidopsis thaliana under salt stress", Bulgarian Journal of Agricultural Science, vol. 26(1), pp. 177-185, 2020 .

[4] Palanivell P, Ahmed OH, Latifah O, Majid NMA., "Economic viability of including crude humic substances, chicken litter biochar, and clinoptilolite zeolite in rice cultivation on acid soils", Bulgarian Journal of Agricultural Science, vol. 25(1), pp. 79-96, 2019.

[5] Bozhanska T., "Application of Lumbrical and Lumbrex biofertilizers and their influence on the nutritional value and quality indicators in artificial grassland of bird's-foot-trefoil (Lotus corniculatus L)", Bulgarian Journal of Agricultural Science, vol. 26(4):761-765. 2020.

[6] Win KT, Okazaki K, Ookawa T, Yokoyama T, Ohwaki Y., 'Effects of biochar and TUAT-1 bio-inoculant on grain yield and nitrogen efficiency of forage rice 'Monster rice 1' under different $\mathrm{N}$ application modes", Archives of Agronomy and Soil Science, 25 May, 2021. https://doi.org/10.1080/03650340.2021.1928089

[7] Blouin M, Barrere J, Meyer N, Lartigue S, Barot S, Mathieu J., "Vermicompost significantly affects plant growth. A meta-analysis", Agronomy for Sustainable Development, pp. 39-34, 2019.

[8] Yatoo AM, Ali MN, Baba ZA, "Hassan B. Sustainable management of diseases and pests in crops by vermicompost and vermicompost tea, a review", Agronomy for Sustainable Development, vol. 41:7, 2021. https://doi.org/10.1007/s13593-020-00657-w
[9] Lightfoot DR., "Morphology and Ecology of Lithic-Mulch Agriculture", Geographical Review, vol. 84(2), pp. 172, 1994. DOI:10.2307/215329

[10] Louder R., "Volcanic ash may be helping vegetation growth. Reykjavik", Grapevine, 2010.

[11] Seward W, Edwards B., "Testing hypotheses for the use of Icelandic volcanic ashes as low cost, natural fertilizers", Geophys. Res. Abstr., p. 178, 2012.

[12] Budiman M, Dian F, Hairiah K, van Noordwijk M., "Applying volcanic ash to croplands - The untapped natural solution", Soil Security 3:100006, 2021. DOI: 10.1016/j.soisec.2021.100006.

[13] Shoji S, Nanzyo M, Dahlgren RA., "Volcanic Ash soils. Genesis, Properties and Utilization", Amsterdam: Elsevier, 1993.

[14] Martínez-Cortizas A, Nóvoa JC, Pontevedra X, García-Rodeja E., "Elemental composition of Reference European", Volcanic Soil Resources in Europe. Reykjavic Iceland., Agricultural Research Institute, 2004.

[15] Litvinenko YS, Zakharikhina LV., "Chemical transformation of Kamchatka soils after input of products of volcanic eruption”, Contemporary Problems of Ecology, $\begin{array}{lll}\text { vol. } 10(6) \text { : } & 686-699, & 2017 .\end{array}$ $10.1134 / \mathrm{S} 1995425517060075$

[16] Zakharikhina LV, Litvinenko YS., "Volcanism and geochemistry of the soil and plant cover in Kamchatka. Part 3 . The elemental composition of vegetation in volcanic ecosystems", Journal of Volcanology and Seismology, vol., 13(3), pp. 149-156, 2019. DOI: 10.31857/S0203-03062019440-51 https://www.elibra ry.ru/item.asp?id=38479061

[17] Ermolin MS, Fedotov PS, Malik NA, Karandashev VK., "Nanoparticles of volcanic ash as a carrier for toxic elements on the global scale", Chemosphere, 200:16-22, 2018.

[18] Taran Y, Campion R, Malik N, Kalacheva E, Melnikov D, Zelenski M, Chaplygin I, Inguaggiato S, Pokrovsky B, Kazahaya R, Fischer T., "Gas emissions from volcanoes of the kuril island arc (nw pacific): geochemistry and fluxes", Geochemistry, Geophysics, Geosystems, vol., 19(6), pp. 1859-1880, 2018. DOI: 10.1029/2018GC007477.

[19] Lansing JS, Kremer JN, Pollard (Gerhart) VJ., "Volcanic fertilization of Balinese rice paddies", Ecological Economics 38 (3): 383-390. 2001. DOI: 10.1016/S0921-8009(01)00173-2

[20] Moiseenko KB, Malik NA., "Estimation of total discharges of volcanic ash using atmospheric-transport models", Journal of Volcanology and Seismology, vol. 9(1), pp. 30-47, 2015. https://elibrary.ru/item.asp?id=24016060

[21] Litvinenko YS, Zakharikhina LV., "Hydrogeochemical zoning of the river network of Kamchatka", Water Resources, vol. 47(2), pp. 269-281, 2020. DOI: $10.1134 / \mathrm{S} 0097807820020098$

[22] Litvinenko YS, Zakharikhina LV., "Zoning and geochemical characterization of volcanic soils on Kamchatka", Geochemistry International, vol. 47(5), pp. 463-475, 2009. 
[23] Shishov LL, Tonkonogov VD, Lebedev II. Classification of soils in Russia", Moscow (M): V.V. Dokuchaev Soil Institute Publ RAAS, 2004.

[24] WRB (World Reference Base for Soil Resources) International soil classification system for naming soils and creating legends for soil maps. World Soil Resources Reports No. 106, Rome: FAO, 2014.

[25] Zakharikhina LV., "Features of soil formation and soil geochemistry under conditions of active volcanism (by the example of Kamchatka)", PhD thesis, Novosibirsk: Novosibirsk State University, 2010.

[26] Dospekhov B.A., "Field experiment methodology (with the basics of statistical processing of research results)",
Moscow: Kolos. 1985.

[27] Karandashev VK, Turanov AN, Orlova TA., "Using mass-spectrometry with inductively coupled plasma for elemental analysis of environmental objects", Factory laboratory. Diagnostics of materials, 73(1):12-22, 2007.

[28] Minaev NS, Filipenko AS, Lebedovsky IA., "On the use of volcanic ash as a natural mineral fertilizer. Scientific support of the agro-industrial complex", Materials of the IX All-Russian Conference of Young Scientists, pp. 45-46, 2016.

[29] Zakharikhina LV, Litvinenko YS. A method for improving the nutritional regime of plants by introducing volcanic ash into the soil. Patent 2637319 RF. 2017. 